5. Ćwięka-Skrzyniarz R. Polonaize. Story of a dance. 5 Manor Drive, 15M Newark, N. J. 07106 USA. 2002.

6. Szalone dni muzyki - polonez dla niepodległej. URL: https://teatrwielki.pl/repertuar/kalendarium/ 2018-2019/szalone-dni-muzyki-polonez-dla-niepodleglej/ (дата звернення: березень 2020).

\title{
REFERENCES
}

1. Bratska, M.V. (2019). Dance in culture: the anthropological context of Ukrainian folk dance in the Polish literature of the nineteenth century. Bulletin of the National Academy of Cultural and Arts Leaders, 1, 216-220 [in Ukrainian].

2. Belza, I.F. (1973). Polonaise. Music Encyclopedia. Ch. ed. Yu.V. Keldysh. Moscow: Sovetskaya entsiklopediya [in Russian].

3. Efremova, I.V. (2014). Embodiment a Ball in the opera "Dubrovsky" by E. Napravnyk. Culture of Ukraine, 47, 177-185 [in Ukrainian].

4. Nidetska, E. (2003). The works of Polish composers of Lvov in the context of Ukrainian-Polish connections (1792-1939). Extended abstract of candidate's thesis. Kyiv [in Ukrainian].

5. Ćwięka-Skrzyniarz, R. (2002). Polonaize. Story of a dance. 5 Manor Drive, 15M Newark, N. J. 07106 USA [in English].

6. Szalone dni muzyki - polonez dla niepodległej. Retrieved from https://teatrwielki.pl/repertuar/ kalendarium/2018-2019/szalone-dni-muzyki-polonez-dla-niepodleglej/ [in Polish].

\author{
УДК 723.28 \\ DOI https://doi.org/10.31723/2524-0447-2020-30-1-5
}

\author{
Аліна Василівна Семенова \\ ORCID: 0000-0002-6829-6587 \\ доцент, заслужена артистка України, \\ завідуюча кафедри оперної підготовки \\ Одеської національної музичної академії імені А. В. Нежданової \\ semalina7@gmail.com
}

\section{ПОЕТИКА «МУЧЕНИЦТВА СВЯТОГО СЕБАСТЬЯНА» К. ДЕБЮССІ В РІЧИЩІ МІСТЕРІАЛЬНИХ ШУКАНЬ СИМВОЛІЗМУ}

\begin{abstract}
Мета роботи - виявлення поетико-інтонаиійної і духовно-смислової унікальності «Мучениитва святого Себастьяна» К. Дебюссі в руслі містеріальних шукань мистеитва символізму. Методологія дослідження має комплексний характер $і$ базується на об'єднанні засад музикознавчого, мистецтвознавчого, історико-культурологічного та міждисциплінарного дослідження. Наукова новизна дослідження визначена його аналітичним ракурсом, зосередженим на співвідношенні поетики «Мучеництва святого Себастьяна» з духовно-естетичними настановами символізму і франиузької культури межі ХІХ-ХХ століть. Висновки. Рубіж ХІХ-ХХ століть у франиузькій культурі характеризується очевидними шуканнями духовної сутності буття, здійснюваними на тлі різноманітних духовно-філософських та стильових систем. Серед останніх суттєве місие належить символізму, показовими ознаками якого є тяэкіння до вишуканого метафоризму, сугестивності, містицизму та музикальності, співвідносними, зокрема, з релігійним світосприйняттям. Одним із яскравих зразків відтворення символістської поетики в музиці є містерія «Мучеництво святого Себастьяна», що виникла на основі творчого союзу між К. Дебюссі та Г. д’Аннунціо. Містеріально-символістський задум цієї вистави апелює до симбіозу біблійних джерел, християнської агіографії (житіє святого Себастьяна), античної міфології (апелювання до образів Аполлона, Адоніса, діви Ерігони), що зумовлюе поліжсанрову природу твору, у якому органічно синтезовані мелодекламація, танець, спів, сиенічна дія й інструментальні епізоди, скориговані задумами декорацій і костюмів Л. Бакста, оригінальною хореографією М. Фокіна, організаційним генієм С. Дягілєва і театральним талантом I. Рубінштейн (виконавиця головної ролі). Органіка їх єднання доповнена інтонаційною мовою містерії, що тяжіє до григоріанської монодії та ранніх форм багатоголосся, гетерофонії. У ролі провідного мотиву-символу виступає квінтова інтонація, що виявляє причетність твору К. Дебюссі до глибинних основ європейської духовно-музичної традиції, їі відтворення в межах символістської поетики початку ХХ століття.
\end{abstract}

Ключові слова: символізм, франиузький символізм, імпресіонізм, містерія, «Мучеництво святого Себастьяна» К. Дебюссі.

(C) Семенова А. В., 2020 
Semenova Alina Vasylivna, Associate Professor, Honored Artist of Ukraine, Head of the Department of Opera Training of the Odessa National A. V. Nezhdanova Academy of Music

Poetics of the "Martyrdom of St. Sebastian" C. Debussy in line with the mysterious quest for symbolism

Research objective is to identify the poetic-intonational and spiritual-semantic uniqueness of the "Martyrdom of St. Sebastian" by C. Debussy in line with the mystery searches of the art of symbolism. The methodology of the work is comprehensive and based on the combination of musicology, art history, cultural and historical and interdisciplinary research. The scientific novelty of the study is determined by its analytical perspective, focused on the correlation of the poetics of the "Martyrdom of St. Sebastian" with the spiritual and aesthetic attitudes of symbolism and French culture at the turn of the XIX-XX centuries. Conclusions. The turn of the $X I X-X X$ centuries in French culture is characterized by obvious searches for the spiritual essence of being, carried out on the basis of a variety of spiritual, philosophical and style systems. Among the latter, a significant place belongs to symbolism, indicative of which is a tendency to exquisite metaphorism, suggestiveness, mysticism and musicality, which are also related to religious perception of the world. One of the striking examples of the implementation of symbolist poetics in music is the mystery "Martyrdom of St. Sebastian", created on the basis of a creative union between C. Debussy and G. d'Annunzio. The mysterious-symbolist design of this performance appeals to the symbiosis of biblical sources, Christian hagiography (the life of St. Sebastian), ancient mythology (appeal to the images of Apollo, Adonis, the virgin Erigona), which determines the multigenre nature of the work, in which melodic dance is organically synthesized, melody stage performance and instrumental episodes, corrected by the designs of L. Bakst's sets and costumes, the original choreography of M. Fokin, the organizational genius of S. Diaghilev, and theatrical talent I. Rubinstein (starring). The organics of their unity is supplemented by the intonational language of the mystery, gravitating to the Gregorian monody and the early forms of polyphony, heterophony. The leading motive-symbol is quinton intonation, revealing the involvement of the work of $C$. Debussy to the deep foundations of the European spiritual and musical tradition and its implementation within the framework of symbolist poetics of the early twentieth century.

Key words: symbolism, French symbolism, impressionism, mystery, "Martyrdom of St. Sebastian” C. Debussy.

Семенова Алина Васильевна, доцент, заслуженная артистка Украины, заведующая кафедрой оперной подготовки Одесской национальной музыкальной академии имени А. В. Неждановой

Поэтика «Мученичества святого Себастьяна» К. Дебюсси в русле мистериальных исканий символизма

Цель работы - выявление поэтико-интонационной и духовно-смысловой уникальности «Мученичества святого Себастьяна» К. Дебюсси в русле мистериальных исканий искусства символизма. Методология исследования носит комплексный характер и базируется на объединении средств музыковедческого, искусствоведческого, историко-культурологического и междисииплинарного исследования. Научная новизна исследования определена его аналитическим ракурсом, сосредоточенным на соотношении поэтики «Мученичества святого Себастьяна» с духовно-эстетическими установками символизма и франиузской культуры рубежса XIX-ХХ столетий. Выводы. Рубеж ХІХ-ХХ столетий во франиузской культуре характеризуется очевидными исканиями духовной сущности бытия, осуществляемыми на основе разнообразных духовно-философских и стилевых систем. Среди последних существенное место принадлежит символизму, показательным признаком которого является тяготение к изысканному метафоризму, суггестивности, мистицизму и музыкальности, соотносимыми, в том числе, и с религиозным мировосприятием. Одним из ярких образиов претворения символистской поэтики в музыке является мистерия «Мученичество святого Себастьяна», созданная в результате творческого союза между К. Дебюсси и Г. д’Аннуниио. Мистериально-символистский замысел этого спектакля апеллирует к симбиозу библейских источников, христианской агиографии (житие святого Себастьяна), античной мифологии (апеллирование к образам Аполлона, Адониса, девы Эригоны), что обусловливает полижанровую природу произведения, в котором органично синтезированы мелодекламация, танеи, пение, сиеническое действие и инструментальные эпизоды, скорректированные замыслами декораций и костюмов Л. Бакста, оригинальной хореографией М. Фокина, организационным гением С. Дягилева и театральным талантом И. Рубинштейн (исполнительница главной роли). Органика их единения дополнена интонационным языком мистерии, тяготеющим к григорианскому монодействию и ранним формам многоголосия, гетерофонии. В роли ведущего мотива-символа выступает квинтовая интонация, выявляющая причастность произведения К. Дебюсси к глубинным основаниям европейской духовно-музыкальной традиции, ее претворению в рамках символистской поэтики начала ХХ столетия.

Ключевые слова: символизм, франиузский символизм, импрессионизм, мистерия, «Мученичество святого Себастьяна» К. Дебюсси.

Актуальність теми дослідження. За влучним висловом М. Бахтіна, «великий творець завжди йде попереду свого часу, він відповідає на не поставлені ще запитання» [цит. за: 6, с. 10]. Дані слова повною мірою співвідносяться із творчою особистістю К. Дебюссі, спадщина якого і нині становить предмет дослідницького інтересу. Сказане багато в чому зумовлено не тільки жанровим, але і стильовим різноманіттям творчості даного автора, співвідносним і з імпресіонізмом, і з антиромантизмом. Окремі опуси 
композитора передбачають типологічні якості музичного неокласицизму. Одним із, безсумнівно, найбільш цікавих дослідницьких аспектів у цьому плані $є$ тема «Дебюссі і символізм». За образним визначенням Л. Кокоревої, що апелює у своїй монографії до дослідження «звукового символізму» як базового творчого методу К. Дебюссі, уся його спадщина - «собор, повний символів, що рухаються в часі» [6, с. 8].

Зазначена стильова «домінанта» творчості К. Дебюссі яскраво проявилася в одному 3 його останніх опусів - містерії «Мучеництво святого Себастьяна» (1911р.), яка вже на момент своєї появи стала об’єктом як різкої критики, так і хвалебних відгуків. Настільки неоднозначна реакція багато в чому зумовлена не тільки співпрацею з Г. д’Аннунціо і його скандальною репутацією, але й із містеріально-символістськими відкриттями самого К. Дебюссі, які ознаменували зрілий і пізній періоди його творчості, що й нині потребують узагальнень музикознавчого й історико-культурологічного порядку.

Російськомовна й україномовна бібліографія, присвячена спадщині великого французького композитора, досить багата і різноманітна, про що свідчать матеріали монографій і публікацій Ю. Кремльова [8], Л. Кокоревої [6; 7], Б. Сгорової [3; 4]. Питання про символістське підгрунтя творчості К. Дебюссі висвітлено в роботі С. Яроцинського «Дебюссі, імпресіонізм і символізм» [19], а також у дослідженні О. Лоскутової й О. Уфімцевої «Звукові шифри Таємниці в символістських концепціях К. Дебюссі і О. Скрябіна» [12].

Містерія «Мучеництво святого Себастьяна» лише в останні десятиліття стала предметом дослідницького інтересу в роботах Ю. Монастиршиної [13], Н. Клімової [5], В. Томахіної [18], Є. Кривицької [9; 10] та інших. Більшість із них стосуються головним чином історії створення твору, його сценічно-виконавської долі, описів характеру співробітництва К. Дебюссі та Г. Д’Аннунціо тощо. Проте питання про зв'язок даного твору із глибинними духовно-смисловими аспектами мистецтва символізму і його містеріальної специфіки поки залишається відкритим, що зумовлює актуальність теми даного дослідження.

Мета дослідження - виявлення поетико-інтонаційної і духовно-смислової унікальності «Мучеництва святого Себастьяна» К. Дебюссі в руслі містеріальних шукань мистецтва символізму. Методологія роботи має комплексний характер і базується на об'єднанні засад музикознавчого, мистецтвознавчого, історико-культурологічного та міждисциплінарного дослідження.

Наукова новизна роботи визначена іiі аналітичним ракурсом, зосередженим на співвідношенні поетики «Мучеництва святого Себастьяна» 3 духовно-естетичними настановами символізму і французької культури межі XIX-XX ст.

Виклад основного матеріалу. Містерія К. Дебюссі була створена в 1911 р., у період розквіту модерну, однією зі складових частин якого виступало мистецтво символізму в усій різноманітності його жанрових і національних моделей, серед яких одне із чільних місць належить його французькій іпостасі.

Межа XIX-XX ст. являє собою грандіозну епоху, потенціал якої виявляється співвідносним за силою й інтенсивністю художнього вираження з попередніми часами (бароко, класицизм, романтизм). Водночас даний період відзначений яскраво вираженими рисами кризи європейської культурно-історичної традиції. Представники творчої еліти стурбовані пошуками нових ідеологій, які відповідали б, на їхню думку, «божевільному часу - «чутливому без сентиментальності і нервовому без хизуючої патологічності». Не випадково, як у калейдоскопі, чергуються: релігійно-філософський ренесанс; екзистенціалізм; марксизм; психоаналіз; ніцшеанство. Виникає враження, що всі течії, що ніби «раптово» з'явилися, $€$ гіпертрофованими «двійниками» тих, що раніше вже існували». На думку О. Лоскутової й О. Уфімцевої, «безглуздо заперечувати, що імпресіонізм, символізм, експресіонізм, сюрреалізм певною мірою спираються на досвід мистецтва романтизму, а модерн узагалі «грає» 3 попередніми епохами і стилями» [12, с. 14].

За таких умов символізм виявився цілком передбачуваним і очікуваним, генетично висхідним до поетики романтичного мистецтва в його спрямованості до сфери Ідеального, елітарного і недомовленого. «Символізм можна метафорично назвати величезною хвилею, яка охопила своєю міццю всю Європу, включаючи Росію, англосаксонську, іберійську і франкомовну Америки. Поступово символізм «переріс» рамки історико-літературного явища $<\ldots>$ і утворив собою новий вимір культурологічного зсуву. Проникнувши в різні види творчого самовираження, символізм змусив цілу епоху говорити своєю мовою. Але ця мова була особливою» [12, с. 15].

Найбільш показові якості символізму групуються навколо уявлень про поета як про творця, причетного до загадкового світу символів і алегорій. У його світосприйнятті 
пріоритетною була творча інтуїція, яка розглядалася на рівні містичного прозріння таємниць буття і спрямованості до розкриття таємниць Вічності і Сенсу всього сущого. У світоглядній системі символізму реальність протиставлялася світу духовному як уособленню вічних ідей і символів та їх художньому відбиттю. Серед найбільш показових виразних якостей мистецтва символізму зазвичай виділяється тяжіння до складного метафоризму, сугестивності, музикальності, образної абстракції, особливого роду вишуканості вираження у прагненні висловити невимовне [див. про це докладніше: 15, с. 48-55].

Так чи інакше поетика символізму в найвищих своїх проявах завжди була орієнтована на ідеї космізму і вселенського перетворення світу і людини у процесах залучення до вищих духовних істин, що багато в чому зумовлює також його співвіднесеність із релігійним світосприйняттям, що становить досить істотний аспект у дослідженні жанровостильової специфіки «Мучеництва святого Себастьяна» К. Дебюссі та його містеріальної жанрової орієнтації. На думку В. Бичкова, «символізм ясно й усвідомлено в особі своїх найбільших представників, як на Заході, так і в Росії, тяжіє до повернення в лоно традиційної релігії, хоча і через культурно-історичні обставини свого часу хотів би внести в неї деякі свої символи, а точніше - позначити по-новому традиційні символи. Водночас мистецтву (як символічному феномену) відводиться суттєва роль шляху до Символу» [1].

Така спрямованість у формуванні символістської картини світу багато в чому визначає іiї явно виражений ірраціональний характер, у якому позначився очевидний відхід від академічного раціоналізму з паралельним зростанням значущості символіко-міфологічної і духовно-релігійної образності. Відзначимо також, що духовні пошуки символізму багато в чому були спрямовані не тільки на формування концепційного синтезу різноманітних релігій, що нерідко об'єднували язичництво і християнство в усьому розмаїтті їхніх проявів, а й на звернення до ранньосередньовічних витоків християнства, зокрема й до його східно-християнської (візантійська) генези. Останнє багато в чому визначає, наприклад, інтерес К. Дебюссі не тільки до архаїки григоріаніки, але й до православної богослужбово-співочої культури, творчо сприйнятої ним, серед іншого, і через творчість М. Мусоргського.

У цьому плані вельми показовими виступають спостереження С. Стоян щодо паралелей між естетикою символізму і візантійською духовно-естетичною практикою. За словами дослідника, «принцип неповного прояву символічного змісту співзвучний ідеям візантійської естетики, в якій ще Псевдо-Діонісій Ареопагіт висловив думку про те, що призначення символічного образу полягає, з одного боку, у виявленні Божественної істини, a, з іншого, в іiі приховуванні від очей невтаємничених» [17]. Зазначимо, що на творчоінтуїтивному рівні осмислення візантійської складової частини символізму відбито і в постановці містерії «Мучеництво святого Себастьяна», відзначеної як оригінальністю інтерпретації образу головного героя Ідою Рубінштейн, так і «візантійським» стильовим тонусом оформлення вистави Л. Бакстом [див. про це докладніше: 4, с. 71].

Така спрямованість духовно-естетичної та художньо-творчої думки багато в чому визначає не тільки зростання ролі релігійного чинника в культурі модерну, французького також, що має також перетини і із процесами «католицького відродження», і пошуками неотомізму (Ж. Марітен, Т. де Шарден та інші), а й зародження у французькому мистецтві початку XX ст. так званого «містеріального театру», головною точкою відліку якого для більшості дослідників стала саме містерія «Мучеництво святого Себастьяна» К. Дебюссі [10, с. 111-112], оскільки обидва її автори «прагнули створити «справжній релігійний твір»» [13, с. 13].

Містерія виникла на основі своєрідного творчого союзу між К. Дебюссі і Г. д’Аннунціо. У ролі об'єднавчого чинника виступив образ ранньохристиянського святого, чий мученицький подвиг був пов'язаний з епохою жорсткого протистояння між раннім християнством і язичницькими віруваннями (III ст. н. е.). Святий Себастьян, згідно з агіографічними джерелами, був ватажком гвардійських (емесських) стрільців римського імператора. Його стійкість у вірі і мучеництво неодноразово привертали увагу багатьох західноєвропейських художників і поетів, особливо в епоху Ренесансу. У рамках західноєвропейської культури образ Себастьяна «поставав в різних іпостасях, то як захисник людей від чуми, то як людина, дивом врятована від смерті, то як християнський герой і мученик, то як втілення духовної краси <...> [10, с. 116].

Відомі численні свідчення щодо масштабної підготовчої роботи Г. д’Аннунціо до створення містерії. Автором був зібраний колосальний іконографічний матеріал, опрацьовано величезну кількість рукописних джерел Паризької національної бібліотеки. П'єса 
написана давньофранцузькою мовою, у «французьких ритмах», які виявляють апелювання автора на кожному кроці «до культурно-історичної пам’яті глядача».

Водночас, відштовхнувшись від численних джерел різних епох, Г. д’Аннунціо формував власний «міф», взявши за зразок, з одного боку, живопис епохи Відродження (Мантенья, А. дель Полайоло), з іншого - екзотичні спектаклі російського балету [Дягілєва]», що мали резонанс у всій Європі початку XX ст. У кінцевому підсумку створений драматургом герой виявився гранично далеким від свого ранньохристиянського аналога. Як зазначає Б. Єгорова, «немає нічого більш далекого від святості, ніж Себастьян д’Аннунціо. Він несе в собі негаразди нового часу, усі лихоманки, усі хвороби, які нас оточують $<\ldots>$ Підліток Себастьян поєднав в одній особі Месію і Антихриста, дияволізм із релігійною екстатичністю» [10, с. 72, 76]. «Своєрідний, майже блюзнірський естетизм д’Аннунціо поєднав язичницьке поклоніння перед красою і містичні екстази католицтва в дусі св. Терези. Образ Себастьяна в цьому контексті набуває особливого значення, втілюючи ніби водночас християнський і язичницький ідеал» [13, с. 14].

Сказане багато в чому визначає поліжанрову природу драми Г. д’Аннунціо, що вмістила йі алюзії-ремінісценції на біблійні джерела, і античні міфи (зі згадками про Адоніса, Аполлона, Діву Ерігону), і середньовічні легенди. У «змішуванні» жанрів даного твору С. Кривицька виділяє такі складники, як: «ранньохристиянська містерія, заснована на уявленні біблійних (або євангельських) епізодів, що з'єднується в д’Аннунціо з ритуалами давньогрецьких містерій і діонісійских ігор. Примітно, що язичницька і християнська тематика у драматурга існують не просто в паралельних площинах: вони активно взаємодіють, утворюють як би дві сторони однієї медалі». У результаті проведеного аналізу сутності такого вражаючого симбіозу дослідник доходить висновку: «Імовірно, ця релігійна амбівалентність і спровокувала Паризького архієпископа на «анафему» «Мучеництва» [10, с. 121].

Позначена жанрова специфіка багато в чому була зумовлена не тільки духовними й естетичними позиціями самого Г. д’Аннунціо і культури його часу, але й специфікою самої епохи (III ст. н. е.), до якої він звернувся у своїй драмі. Вона, як вказувалося раніше, має рубіжний характер, виявляє якості перехідності і взаємопроникнення язичництва i християнства, у рамках якого нерідко виникали аналогії-паралелі між образом Ісуса Христа і представниками античного пантеону (Аполлон, Орфей) [див. про це докладніше: 14].

Є. Кривицька виділяє такі паралелі між античним і християнським світосприйняттям і зазначає «очевидні асоціації з діонісійськими іграми і «Мучеництвом», одним із центральних епізодів якого стає танець Себастьяна, що зображує Страсті Христові». Ефект «накладення» у 3-й частині твору образів Христа й Адоніса як алегорій смерті і воскресіння доповнюється аналогічними «трансформаціями образу діви Ерігони (також персонаж корпусу античних міфів про Діоніса), яка перевтілюється в Богоматір». Перетин античної міфології та християнської символіки простежується і в 4-й частині містерії, де описано страту Себастьяна, «прив'язаного до стовбура стародавнього лавра в гаю Аполлона, на який ув сутінках падає тінь Доброго пастиря» [9, с. 117].

Підхід К. Дебюссі до цього сюжету і героя аж ніяк не тотожний позиції автора літературного першоджерела, про що свого часу писав сам композитор: «Я вважаю себе зобов’язаним писати музику тільки для тих місць, які, наскільки я можу судити, гідні бути омузикаленими: це кілька хорів і, як мені здається, трохи музики по ходу дії» [2, с. 191-192]. Практично всі фрагменти твору Г. д’Аннунціо, обрані К. Дебюссі для озвучування, більш орієнтовані не на сюжетно динамічні, дієві сцени, а на містеріальні епізоди. «Там, де крізь тимчасовий потік бачиться вічне, там починає звучати музика Дебюссі, що супроводжує дива, молитви, екстатичні бачення й образи» [13, с. 10], виявляючи тим самим типові якості містеріального музичного театру, який визначив один зі шляхів його розвитку у ХХ ст.

Для К. Дебюссі робота над даною містерією стала також утіленням його «власної віри», пошуків «синтетичної релігії», про що він згадує у своїх статтях. За словами композитора, власне духовна музика в іiі істинному розумінні закінчується для нього в XVI ст. У наступний період «благочестиві музичні імпровізації мали завжди більш-менш показний характер», за винятком творчості Й.С. Баха. К. Дебюссі віддає належне християнській складовій частині творчості своїх великих попередників і сучасників, проте усвідомлює статус даної сфери творчості, пов'язаної з Висотою Духа. За його словами, «необхідна зовсім інша відмова від самого себе, щоб оспівувати Божественне. Треба віддатися цій справі з героїчною великодушністю і постійною відмовою від чого б то не було і від самого себе» [2, с. 191].

К. Дебюссі критично оцінював свій ступінь наближеності до сакрального, неодноразово наголошував: «Я сам дуже далекий від цього стану благодаті. Я ж не дотримуюся 
релігійних обрядів за встановленим ритуалом. Я створив собі релігію 3 таємничих сил природи <...> Всеосяжна природа відбивається в моїй душі <...> I непомітно руки самі складаються в молитовні жести <...> Відчути, якими величними і вражаючими $є$ ті видовища, які природа пропонує нам - примарним і тремтячим перехожим, - ось що я називаю «молитися»» [2, с. 191]. У кінцевому підсумку композитор стверджував, що писав музику до містерії «Мучеництво святого Себастьяна» так, «ніби вона була задана для церкви» [13, с. 13]. У цій позиції очевидна не тільки глибина віри К. Дебюссі й усвідомлення ним величі Божественного творіння, але осмислення-прийняття цілісності Всесвіту в органічній єдності його духовного і світського начал, що, на наш погляд, становить одну з найважливіших типологічних якостей містерії, виділеної автором як жанрове визначення свого опусу.

Містерія - один із найдавніших жанрів, що об’єднує релігійні та культурно-історичні традиції різних епох. «Модус містеріальності» сконцентрований на певних тезах, які $є$ значущими для різних релігійно-мистецьких практик. Ю. Куранова узагальнює їхню сутність і зазначає, що «містерія завжди релігійна, вона має на увазі віру у вищі начала буття язичницьких богів давнини або єдиного християнського Бога. Містерія - це поклоніння Богові, а також прагнення до поєднання з Ним <..> і відновлення втраченої гармонії в душі і світі і, тим самим, підтримання космічного порядку. Для досягнення останнього необхідно стати обраним для посвячення в таємниці і пройти ряд випробувань, які символізують жертовність, у ході яких виникають акти ієрофанії і теофанії <...> Містеріальне дійство завжди існує в нерозривній єдності релігійного ритуалу і театралізованого уявлення. Причому театральне, або ігрове, начало підпорядковане ритуалу, через який встановлюються порядок речей у природі і гармонія світобудови» [11, с. 24-25].

Окреслені типологічні якості містерії повною мірою представлені і в розглянутому творі К. Дебюссі. Його основу становить агіографічний сюжет, репрезентований у традиціях культури модерну, стурбованого духовними пошуками «синтезу релігій». Оригінальний симбіоз античної та християнської міфології в кінцевому підсумку увінчаний у фінальній частині («Рай») містерії домінуванням саме християнських настанов, репрезентованих у хорах апостолів, ангелів, душ мучеників, об'єднаних глоріозним славослів'ям, що символізує також ідею торжества космічного Порядку. Мученицький шлях Себастьяна стає водночас шляхом його духовного сходження і возз'єднання з Богом, що є очевидним і для земного, і для небесного світів.

Окреслені ідеї реалізуються творчою спілкою Г. д’Аннунціо і К. Дебюссі на рівні масштабного багатогодинного дійства, що включає п’ять частин-актів («Двір лілій», «Чудова кімната», «Світло неправдивих богів», «Поранений лавр», «Рай»), які об’єднують в єдине ціле мелодекламацію, танець, спів, сценічну дію, інструментальні прелюдії й інтерлюдії, скориговані задумами декорацій і костюмів Л. Бакста, оригінальною хореографією М. Фокіна, організаційним генієм С. Дягілєва і театральним талантом I. Рубінштейн (виконавиця головної ролі).

Містеріальний задум твору визначає, відповідно, його музичну мову. Головна роль християнського чинника зумовлює істотну роль у ньому традицій григоріаніки, до якої К. Дебюссі виявляв значний інтерес і в попередні періоди творчості. Відомий факт його перебування в 1894 р. в абатстві Солем, де композитор активно вивчав католицьку богослужбово-співочу традицію. Іїі досвід відчутний і в «Пеллеасі і Мелізанді», і в «Мучеництві святого Себастьяна». У численних хорових епізодах останнього твору домінує монодія. Широко використовуються також і ранні форми багатоголосся, зокрема й рух паралельними секстакордами (Хор незайманих із V ч.), гімель, різноманітні форми гетерофонії. На думку Л. Кокоревої, «саме Дебюссі відкрив заново красу одноголосного хорового співу, який став важливою стильовою ознакою ораторії» [аналізованої містеріі]. Такого роду спів виявляє не тільки григоріанські «пристрасті» композитора, але й його прагнення до відтворення «співу в дусі античної трагедії» (з урахуванням значної ролі у творі героїв античної міфології)» [6, с. 454].

Суттєва у творі також роль мотивів-символів (термін Л. Кокоревої - $A$. C.). Серед таких особливо виділяється квінта, сполучена нерідко з терцією і секундою, що виконує роль своєрідного лейтінтервалу. Зауважимо, що квінтовість є вельми показовою для культової співочої практики різних християнських конфесій. Досвід серйозного вивчення григоріаніки доповнювався в К. Дебюссі також інтересом і до російської співочої традиції. «Квінтовість», як відомо, становить характерну якість як певних жанрових сфер російського фольклору, так і православної богослужбово-співочої практики [див. про це докладніше: 16, с. 145], однаково близьких і дорогих композитору і творчо сприйнятих через інтонаційну сферу спадщини російських музикантів, особливо М. Мусоргського. 
Зазначена лейтінтервальна специфіка містерії К. Дебюссі багато в чому визначає інтонаційну сферу твору, виявляє тим самим іiі драматургічні особливості, що не потребують уведення спеціальних лейтмотивів. На думку Є. Кривицької, «тут спостерігається спільність первинного інтонаційного комплексу, на основі якого К. Дебюссі з разючою майстерністю створює контрастні за фактурою і образним рядом музичні номери» [10, с. 135].

Висновки. Отже, межа XIX-XX століть у французькій культурі характеризується очевидними шуканнями духовної сутності буття, здійснюваними на тлі різноманітних духовнофілософських та стильових систем. Серед останніх суттєве місце належить символізму, показовими ознаками якого є тяжіння до вишуканого метафоризму, сугестивності, містицизму та музикальності, співвідносними, серед іншого, і з релігійним світосприйняттям. Одним із яскравих зразків відтворення символістської поетики в музиці є містерія «Мучеництво святого Себастьяна», що виникла завдяки творчому союзу між К. Дебюссі та Г. д’Аннунціо. Містеріально-символістський задум цієї вистави апелює до симбіозу біблійних джерел, християнської агіографії (житіє святого Себастьяна), античної міфології (апелювання до образів Аполлона, Адоніса, діви Ерігони), що зумовлює поліжанрову природу твору, у якому органічно синтезовані мелодекламація, танець, спів, сценічна дія й інструментальні епізоди, скориговані задумами декорацій і костюмів Л. Бакста, оригінальною хореографією М. Фокіна, організаційним генієм С. Дягілєва і театральним талантом I. Рубінштейн (виконавиця головної ролі). Органіка їх єднання доповнена інтонаційною мовою містерії, що тяжіє до григоріанської монодії та ранніх форм багатоголосся, гетерофонії. У ролі провідного мотиву-символу виступає квінтова інтонація, що виявляє причетність твору К. Дебюссі до глибинних основ європейської духовно-музичної традиції, iii відтворення в межах символістської поетики початку XX ст.

\section{СПИСОК ЛІТЕРАТУРИ}

1. Бычков В. В. Эстетические пророчества русского символизма. URL: www.vehi.net/soloviev/ bychkov2.html (дата звернення: 12.12.2019).

2. Дебюсси К. Статьи. Рецензии. Беседы. Москва ; Ленинград : Музыка, 1964. 278 с.

3. Егорова Б. Дебюсси и прерафаэлиты. Искусства XX века: диалог эпох и поколений : сборник статей. Нижний Новгород, 1999. Т. 1. С. 73-88.

4. Егорова Б. Дебюсси и стиль модерн. Нижний Новгород : Нижегородская государственная консерватория (академия) им. М.И. Глинки, 2009. 160 с.

5. Клімова Н. Містерія «Мучеництво святого Себастіана» та принципи оперного театру Клода Дебюссі. Часопис Національної музичної академії України імені П.І. Чайковського : науковий журнал. 2013. № 1 (18). С. 37-42.

6. Кокорева Л. Клод Дебюсси : исследование. Москва : Музыка, 2010. 498 с.

7. Кокорева Л. Язык символизма - поэтический и музыкальный: от «Пеллеаса» к «Воццеку». Музыкальная академия. 2002. № 4. С. 143-151.

8. Кремлев Ю. Клод Дебюсси. Москва : Музыка, 1965. 792 с.

9. Кривицкая Е. Лики святого Себастьяна. Музыкальная академия. 2009. № 3. С. 115-124.

10. Кривицкая Е. Музыка Франции: век двадцатый. Эстетика, стиль, жанр. Москва ; СанктПетербург : Центр ГИ, 2012. 336 с.

11. Куранова Ю. Модус мистериальности в музыкальном театре И.Ф. Стравинского («Весна священная», «Персефона», «Потоп») : дис. ... канд. искусствоведения: 17.00.02. Москва, 2017. 249 с.

12. Лоскутова О., Уфимцева Е. Звуковые шифры Тайны в символистских концепциях К. Дебюсси и А. Скрябина : монография. Уральская государственная консерватория им. М.П. Мусоргского. Екатеринбург, 2007. 156 с.

13. Монастыршина Ю. Мистерия Дебюсси «Мученичество святого Себастьяна» в культурном контексте эпохи : автореф. дис. ... канд. искусствоведения: 17.00.02. Москва, 2000. 26 с.

14. Мутер Р. Всемирная история живописи. Средневековье и ранний Ренессанс. От Византии к Италии. Москва : Эксмо, 2006. 144 с.

15. Ніколенко О. Поезія французького символізму. Шарль Бодлер, Поль Верлен, Артюр Рембо : посібник для вчителя. Харків : Веста ; Ранок, 2003. 144 с.

16. Руднева А. Русское народное музыкальное творчество : очерки по теории фольклора. Москва : Советский композитор, 1990. 224 с.

17. Стоян С. Западноевропейский символизм как художественное направление: культурнофилософские детерминанты. Актуальные проблемы гуманитарных и естественных наук. 2015. № 2-1. URL: publikacia.net/archive/2015/2/1/54 (дата звернення: 12.12.2019).

18. Томахина В. Мистерия «Мученичество святого Себастьяна» Аннунцио - Дебюсси. О создании и создателях. Исторические, философские, политические и юридические науки, культурология и искусствоведение. Вопросы теории и практики. Тамбов : Грамота, 2012. № 12 (26) : в 3-х ч. Ч. II. С. 197-199.

19. Яроциньский С. Дебюсси, импрессионизм и символизм. Москва : Прогресс, 1978. 232 с. 


\section{REFERENCES}

1. Bychkov, V.V. (2019). Aesthetic prophecies of Russian symbolism. Retrieved from www.vehi.net/ soloviev/bychkov2.html

2. Debyussi, K. (1964). Articles. Reviews. Conversations. Moscow - Leningrad: Muzyka [in Russian].

3. Yegorova, B. (1999). Debussy and the Pre-Raphaelites. Iskusstva XX veka: dialog epokh i pokoleniy. Sbornik statey. 1, pp. 73-88 [in Russian].

4. Yegorova, B. (2009). Debussy and Art Nouveau. Nizhny Novgorod: Nizhegorodskaya gosudarstvennaya konservatoriya (akademiya) im. M.I. Glinki [in Russian].

5. Klimova, N.I. (2013). The Mystery of the Martyrdom of St. Sebastian and the Principles of the Claude Debussy Opera. Chasopys NMAU im. P.I. Chaykovs'koho: Naukovyy zhurnal. 1 (18), pp. 37-42 [in Ukrainian].

6. Kokoreva, L. (2010). Claude Debussy: Research. Moscow: Muzyka [in Russian].

7. Kokoreva, L. (2002). The language of symbolism is poetic and musical: from Pellŭas to Wozzeck. Muzykal'naya akademiya. 4, pp. 143-151 [in Russian].

8. Kremlev, Y.A. (1965). Claude Debussy. Moscow: Muzyka [in Russian].

9. Krivitskaya, E. (2009). Faces of St. Sebastian. Muzykal'naya akademiya. 3, pp. 115-124 [in Russian]. 10. Krivitskaya, E. (2012). Music of France: twentieth century. Aesthetics, style, genre. Moscow St. Petersburg: Tsentr GI [in Russian].

11. Kuranova, Yu.A. (2017). The modus of mystery in the musical theater of I.F. Stravinsky ("The Rite of Spring", "Pesefona", "Flood"). Candidate's thesis. Moscow: Rossiyskaya akademiya muzyki imeni Gnesinykh [in Russian].

12.Loskutova, O.V., Ufimtseva, Ye.A. (2007). Sound Ciphers Secrets in the Symbolist Concepts of C. Debussy and A. Scriabin: Monograph. Yekaterinburg: Ural'skaya gosudarstvennaya konservatoriya im. M.P. Musorgskogo [in Russian].

13. Monastyrshina, Yu.A. (2000). Mystery Debussy "The Martyrdom of Saint Sebastian" in the cultural context of the era. Extended abstract of candidate's thesis. Moscow: Moskovskaya gosudarstvennaya konservatoriya im. P.I. Chaykovskogo [in Russian].

14. Muther, R. (2006). World history of painting. The Middle Ages and the Early Renaissance. From Byzantium to Italy. Moscow: Eksmo [in Russian].

15. Nikolenko, O.M. (2003). Poetry of French symbolism. Charles Baudelaire, Paul Verlaine, Arthur Rimbaud: A Teacher's Guide. Kharkiv: Vesta: Vydavnytstvo "Ranok" [in Ukrainian].

16. Rudneva, A.V. (1990). Russian folk music: essays on the theory of folklore. Moscow: Sovetskiy kompozitor [in Russian].

17.Stoyan, S. P. (2015). Western European Symbolism as an Artistic Direction: Cultural and Philosophical Determinants. Aktual'nyye problemy gumanitarnykh $i$ yestestvennykh nauk. Retrieved from publikacia.net/ archive $/ 2015 / 2 / 1 / 54$.

18. Tomakhina, V.P. (2012). Mystery of "The Martyrdom of St. Sebastian" Annunzio - Debussy. About creation and creators. Istoricheskiye, filosofskiye, politicheskiye i yuridicheskiye nauki, kul'turologiya i iskusstvovedeniye. Voprosy teorii i praktiki. 12 (26), pp. 197-199 [in Russian].

19. Yarotsin'skiy, S. (1978). Debussy, impressionism and symbolism. Moscow: Progress [in Russian]. 